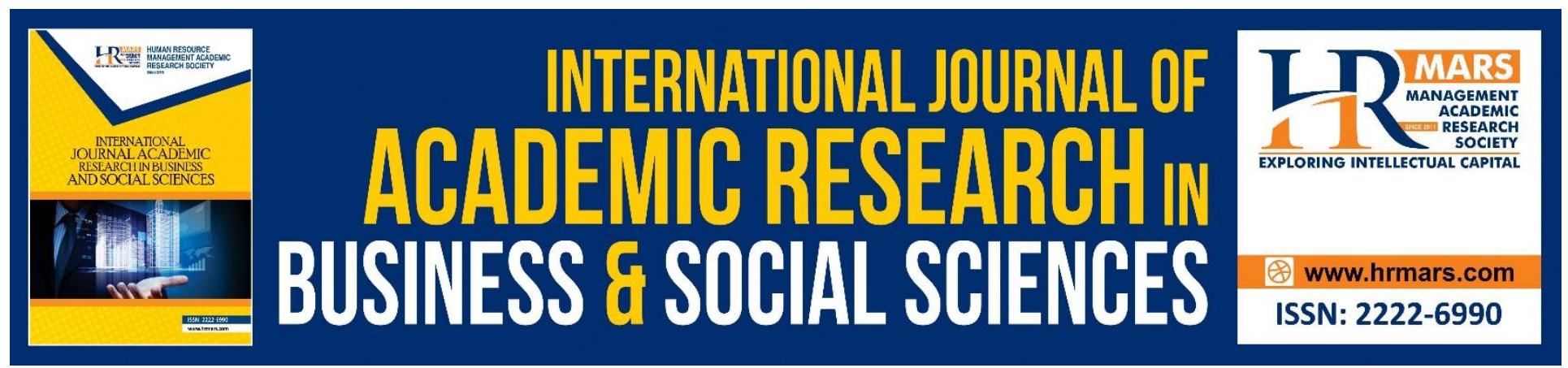

\title{
The Influence of Learner's Motivation and Attitudes on Foreign Language Learning among Malaysian Students in UPSI
}

Mariyati Haji Mohd Nor, Robe'ah Yusuf, Norhana Md. Salleh

To Link this Article: http://dx.doi.org/10.6007/IJARBSS/v9-i1/5494

DOI: $\quad 10.6007 /$ IJARBSS/v9-i1/5494

Received: 29 Dec 2018, Revised: 17 Jan 2019, Accepted: 30 Jan 2019

Published Online: 03 Feb 2019

In-Text Citation: (Nor, Yusuf, \& Salleh, 2019)

To Cite this Article: Nor, M. H. M., Yusuf, R., \& Salleh, N. M. (2019). The Influence of Learner's Motivation and Attitudes on Foreign Language Learning among Malaysian Students in UPSI. International Journal of Academic Research in Business and Social Sciences, 9(1), 950-962.

\section{Copyright: (C) 2019 The Author(s)}

Published by Human Resource Management Academic Research Society (www.hrmars.com)

This article is published under the Creative Commons Attribution (CC BY 4.0) license. Anyone may reproduce, distribute, translate and create derivative works of this article (for both commercial and non-commercial purposes), subject to full attribution to the original publication and authors. The full terms of this license may be seen at: $\underline{\text { http://creativecommons.org/licences/by/4.0/legalcode }}$

Vol. 9, No. 1, 2019, Pg. 950 - 962

Full Terms \& Conditions of access and use can be found at http://hrmars.com/index.php/pages/detail/publication-ethics 


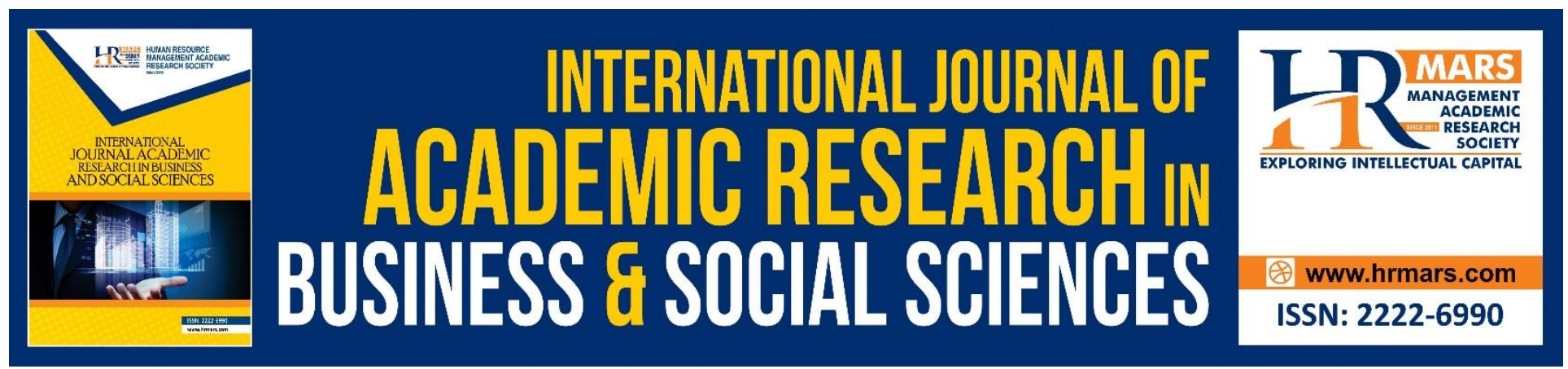

\title{
The Influence of Learner's Motivation and Attitudes on Foreign Language Learning among Malaysian Students in UPSI
}

\author{
Mariyati Haji Mohd Nor \\ Asian and European Language Unit, Centre For Languages and General Studies, Sultan Idris \\ Education University \\ Robe'ah Yusuf \\ Asian and European Language Unit, Centre For Languages and General Studies, Sultan Idris \\ Education University
}

Norhana Md. Salleh

Asian and European Language Unit, Centre For Languages and General Studies, Sultan Idris Education University

\begin{abstract}
Leaner's motivation and attitudes have great impact on the foreign language learning. The objective of this study was to determine the motivation and attitudes of the students towards learning foreign languages among Malaysian students in Sultan Idris Education University (UPSI). This study measured the attitudes through the motivation of students on the basis of Gardner's SocioEducational Model (1985). In order to reveal the co-relation between motivation and attitudes of language learners and the foreign language learning, the study designs a set of questionnaire to investigate the student's learning attitude and motivation towards learning process of all the three languages involved (Spanish, German and Japanese). A total of 90 respondents involved in this study comprising of 30 Spanish, 30 German and 30 Japanese language students. Through discussion of the survey, the respondents have showed positive attitudes and motivation towards learning process of all the three languages. The study found out that the motivation of the students to attend foreign languages courses was influenced by the internal factors like preferences, interests and enjoyment in learning foreign languages. In addition, integrative and instrumental factors also influenced the attitudes of the students. The results show that some students are motivated intrinsically in that they learn foreign languages for the purpose of communicating with foreigners, or for an interest in European and Asian Culture, or even learning foreign languages to earn a new experience. Some
\end{abstract}


INTERNATIONAL JOURNAL OF ACADEMIC RESEARCH IN BUSINESS AND SOCIAL SCIENCES

Vol. 9, No. 1, Jan, 2019, E-ISSN: 2222-6990 (C) 2019 HRMARS

students are motivated due to the extrinsic factors such as for the purpose of career development, higher education or travel. In conclusion, UPSI students have positive attitudes and motivation towards foreign language that is being learned.

Keywords: Attitude, Foreign Language, Learning, Interest, Motivation, Model, Students

\section{Introduction}

Learning a foreign language in a country that is not the native and multilingual such as Malaysia, requires readiness from the students in terms of mental, physical and emotional involving various factors (Baker, 1992). In addition to differences of attitudes among students which affect the process of language learning, there are other factors involved such as age, sex, social condition, political, economic and others. Although there are many other factors that determine the success of learning a foreign language as the third language and so on, psychological experts agreed that attitude is the most important factor that will influence the success and failure in the achievement of a student. Positive attitude such as motivation and attitudes contribute to learning. Strong interest and effort in learning will help students to master the language that is being learned quickly, easily and effectively. Students always think of appropriate and effective strategies to enhance skills in learning. While negative attitudes such as anxiety, fear and depression hinder a learner's potential learning abilities and will cause difficulty in learning and mastering the language that is being learned. Therefore, foreign language teaching and learning should pay more attention to study of the internal (emotional) factors to help students eliminate their negative psycholigical factors and promote positive affection to learning (Zhao, 2015).

\section{Socio-Educational Model (Gardner, 1985)}

The theory of foreign language acquisition as second or third language by Gardner and Smythe (1975) in Mohd Firdaus (2003) was defined through theoretical model known as the SocialEducational Model. This model explained the attitudes and motivation of students towards second language or foreign language were influenced by social characteristics that can be found in the surrounding areas. Students who came from different backgrounds of families and communities would show different attitudes towards foreign language. In addition, factors such as teachers or lecturers, peers and classmates, learning activities and environment would support and influence the attitudes of students in learning foreign languages. Researchers will use the views and SocioEducational Model' by Gardner (1985) as the basis for this research. 
INTERNATIONAL JOURNAL OF ACADEMIC RESEARCH IN BUSINESS AND SOCIAL SCIENCES

Vol. 9, No. 1, Jan, 2019, E-ISSN: 2222-6990 @ 2019 HRMARS

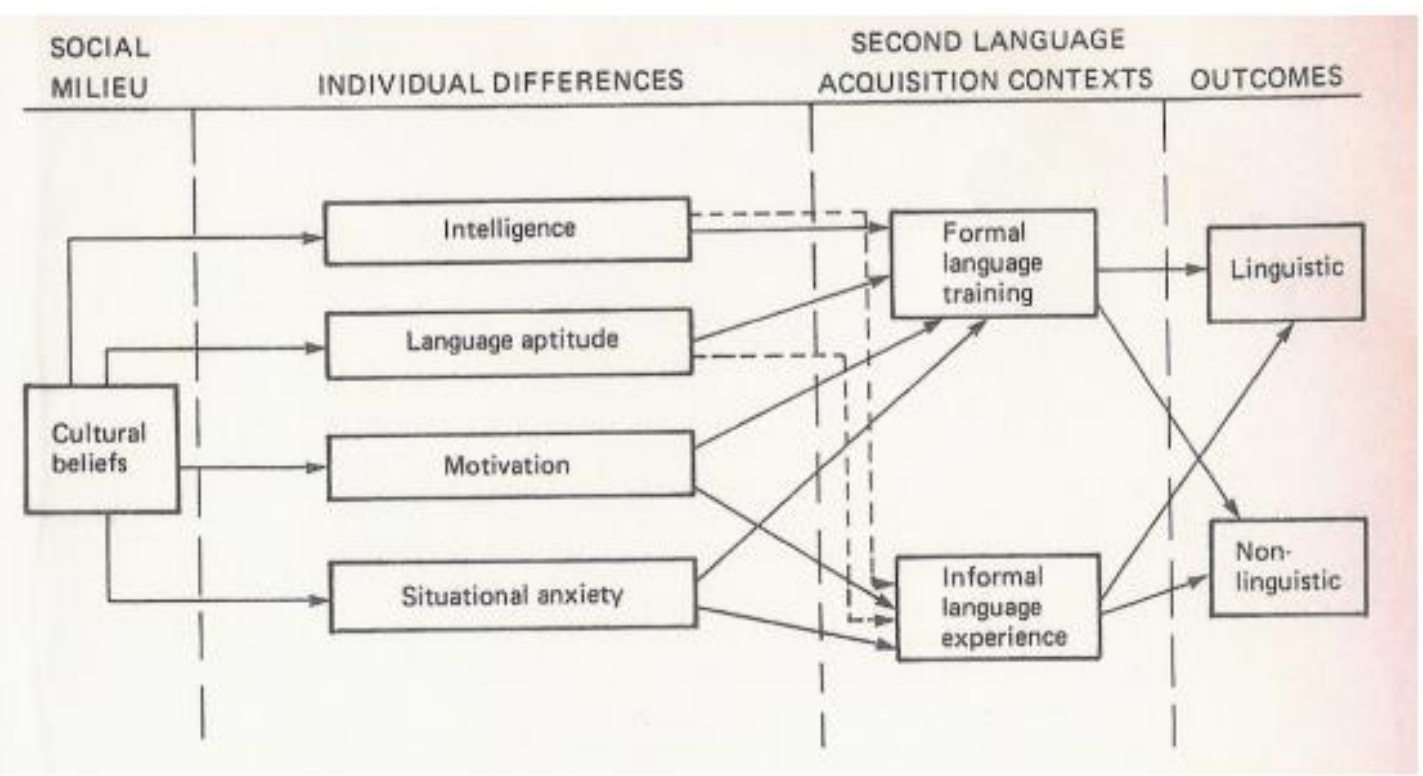

Figure 1: Socio-Educational Model by Gardner (1985)

According to Gardner (1985), this Socio-Educational Model indicates the importance of learning a language regardless as the first, second or foreign language. Gardner believed that language acquisition involved; belief in context of a particular culture and also the role of variety of individual differences. The above model as well shows that if the cultural aspect is regarded as the most difficult aspect by students to dominate, then the student's level of achievement and language mastery will be low and difficult (Gardner, 1985 in Derek, 2009). In terms of individual differences in learning language, Gardner said that there were 4 individual differences that would determine the achievement in learning a language; which were intelligence, tendency, motivation and anxiety. Students will be able to master a language well where there are interest, positive perception towards culture and the language. This is related to intelligence, motivation, tendency and anxiety about situations that influence individual differences in languages learning and thus influence the attitudes of students. In this study, researchers will look on attitudes, motivation, interests and perceptions of students towards foreign languages learning in UPSI and how these aspects influence the attitudes of students.

Intelligence is considered to measure the extent to which an individual manage to understand all the given assignments and explanations during the process of languages learning. On the other hand, according to Cook (1991), language tendency is the student's ability to learn second language in academic classes and it is associated with the intelligence of the students. While motivation refers to the effort, desire and result related to learning a second language (Gardner in Derek, 2009). Motivation is very vital in languages learning as it will influence attitudes and determine the extent to which an individual learns to acquire language. The aspect of situational refers to fear that appears in the students towards the language learned and it can be as a barrier in the process of learning the language. In this study, researchers will focus on the aspect of motivation, interests and perceptions as well as its relationship with student's attitudes. 
Socio-Educational Model also shows two contexts of language learning that can take place, namely formal and informal. In this study, learning occurred formally in classroom. While informal context refers to other purposes of learning that happen for the purpose of entertainment or communication.

Learning process that happens will give results which are linguistic and non-linguistic. Both of the results depend on the experience in both contexts of learning language. The result of linguistic refers to language proficiency such as knowledge, vocabulary, grammar and fluency in speaking, while non-linguistic results refer to the attitudes, values and so on (Gardner, 1985).

\section{METHODOLOGY OF THE STUDY}

\section{Participant}

In order to find out the influences that motivation and attitude bring about to foreign language learners, a total of 90 students involved in this study. 30 students for Spanish, German and Japanese language were investigated. They are all majors in education. They differ from each other in their races, courses, learning motivation and attitude. Data was collected by distributing questionnaire to the UPSI students who registered for courses of foreign languages in the Department of Modern Languages, Faculty of Languages and Communication, UPSI. In terms of gender, female students $(58.9 \%)$ were more than male $(41.1 \%)$ respectively. In terms of ethnicity, Malay (58.9\%) students were more than Chinese students (20\%). There were $7(7.8 \%)$ Indian students and 12 students representing the other races (13.3\%).

\section{Procedure}

The survey is made in the following steps

a) The lecturer collects some typical questionnaires that investigating the attribution of student's motivation of third language learning and their attitudes towards foreign language learning. In this study a set of questionnaire consisting of closed questions was used to alleviate the process of analyzing data by using the Statistical Package for the Social Sciences software (SPSS). Likert scale which consisted of five levels of measurement ( $1=$ Strongly Disagree $2=$ Disagree, $3=$ Moderate, $4=$ Agree 5 = Strongly Agree) was used to explain the opinions of students in a more detail way.

b) The lecturer asks the students to fill in the investigation form with regard to the affective factors that have influence on student's motivation to learn the languages. Afterwards, the lecturer collects the data and counts out the percentage of each item. The table and the chart are shown below.

A set of questionnaire consisting two parts of questions are conducted from the perspectives of student's learning motivation and attitudes and the attibution of student's motivation in learning. In table 4, a question is raised by the lecturer about the student's motivation and attitudes towards learning Spanish, German and Japanese. 12 items are proposed for the student's motivation and followed by 8 items for student's attitude toward learning the foreign language to be answered. In 
INTERNATIONAL JOURNAL OF ACADEMIC RESEARCH IN BUSINESS AND SOCIAL SCIENCES

Vol. 9, No. 1, Jan, 2019, E-ISSN: 2222-6990 @ 2019 HRMARS

table 2, a survey about student's attribution for learning is made to figure out the factors that have influence the students to learn the language.

\section{Results and Discussions}

\section{The level of motivation}

Motivation refers to goal- directed behavior (cf.Hechkhausen, 1991), and when one is attempting to measure motivation, attention can be directed toward a number of features of the individual. In this study, the results to identify the level of student's motivation were showed in the table 4 below. The table shows twelve statements that measured student's motivation in foreign language courses. In this study the items were categorized into five levels. Evaluation of level determination was based on the mean score for each question in each category. Guide to grading levels are; Level 1:1.00 - 1.49 (very negative), level 2:1.50 - 2.49 (negative) level 3:2.50 - 3.49 (neutral) level 4:3.50 - 4.49 (positive) and level 5: $4.50-5.00$ (very positive). The guide of grading level was customized from the study of Hieda and Maserah (2014).

\begin{tabular}{|c|c|c|c|c|c|c|}
\hline No & Statement & Disagree & Agree & mean & sp & level \\
\hline \multirow[t]{2}{*}{1} & \multirow{2}{*}{$\begin{array}{l}\text { I am interested to enroll in a foreign language course of } \\
\text { my choice that is offered in this university }\end{array}$} & 4 & 86 & \multirow[t]{2}{*}{4.59} & \multirow[t]{2}{*}{0.58} & \multirow[t]{2}{*}{4} \\
\hline & & $4.4 \%$ & $95.6 \%$ & & & \\
\hline \multirow[t]{2}{*}{2} & \multirow{2}{*}{$\begin{array}{l}\text { I found that the foreign language subject of my choice } \\
\text { was very interesting compared to other subjects }\end{array}$} & 14 & 76 & \multirow[t]{2}{*}{4.29} & \multirow[t]{2}{*}{0.75} & \multirow[t]{2}{*}{4} \\
\hline & & $15.6 \%$ & $84.4 \%$ & & & \\
\hline \multirow[t]{2}{*}{3} & \multirow{2}{*}{$\begin{array}{l}\text { I learn the foreign language of my choice because the } \\
\text { tone sounds interesting }\end{array}$} & 29 & 61 & \multirow[t]{2}{*}{3.98} & \multirow[t]{2}{*}{0.87} & \multirow[t]{2}{*}{4} \\
\hline & & $32.2 \%$ & $67.8 \%$ & & & \\
\hline \multirow[t]{2}{*}{4} & \multirow{2}{*}{$\begin{array}{l}\text { I choose to learn this foreign language in order to visit } \\
\text { the particular country }\end{array}$} & 29 & 61 & \multirow[t]{2}{*}{3.91} & \multirow[t]{2}{*}{1.20} & \multirow[t]{2}{*}{4} \\
\hline & & $32.2 \%$ & $67.8 \%$ & & & \\
\hline \multirow[t]{2}{*}{5} & \multirow{2}{*}{$\begin{array}{l}\text { I am very happy to learn the foreign language of my } \\
\text { choice }\end{array}$} & 8 & 82 & \multirow[t]{2}{*}{4.52} & \multirow[t]{2}{*}{0.66} & \multirow[t]{2}{*}{4} \\
\hline & & $8.9 \%$ & $91.1 \%$ & & & \\
\hline \multirow[t]{2}{*}{6} & \multirow{2}{*}{$\begin{array}{l}\text { I am interested to listen to the foreign language songs } \\
\text { particularly the language of my choice }\end{array}$} & 23 & 67 & \multirow[t]{2}{*}{4.13} & \multirow[t]{2}{*}{0.90} & \multirow[t]{2}{*}{4} \\
\hline & & $25.6 \%$ & $74.4 \%$ & & & \\
\hline \multirow[t]{2}{*}{7} & \multirow{2}{*}{$\begin{array}{l}\text { I like to learn foreign language of my choice because is } \\
\text { easy }\end{array}$} & 3 & 87 & \multirow[t]{2}{*}{4.62} & 0.55 & 4 \\
\hline & & $3.3 \%$ & $96.7 \%$ & & & \\
\hline 8 & I enrolled in the foreign language course of my choice & 17 & 73 & 4.24 & 0.75 & 4 \\
\hline & in order to be able to understand films in that language. & $18.9 \%$ & $81.1 \%$ & & & \\
\hline 9 & I chose to learn this foreign language in order to get & 20 & 70 & 4.22 & 0.82 & 4 \\
\hline & better job opportunity after graduation. & $22.2 \%$ & $77.8 \%$ & & & \\
\hline 10 & Skills in the foreign language that I have chosen will be & 17 & 73 & 4.17 & 0.72 & 4 \\
\hline & $\begin{array}{l}\text { able to help me to understand the cultures of the } \\
\text { native speaker. }\end{array}$ & $18.9 \%$ & $81.1 \%$ & & & \\
\hline 11 & The need of mastering foreign language of my choice is & 20 & 70 & 4.13 & 0.82 & 4 \\
\hline & $\begin{array}{l}\text { due to its importance in the global level and for the } \\
\text { purpose of future. }\end{array}$ & $22.2 \%$ & $77.8 \%$ & & & \\
\hline 12 & I will be considered as smart when knowing foreign & 55 & 35 & 3.33 & 1.09 & 3 \\
\hline & language particularly the one that I chose. & $61.1 \%$ & $38.9 \%$ & & & \\
\hline Tot & & & 4.18 & & 0.81 & 3.91 \\
\hline
\end{tabular}

Table 4:Level Motivation

From the data analysis of table 4, we can get the conclusion that the students's motivation toward learning foreign languages is positive. It could be seen in the overall mean value of 4.18 (standard deviation $=0.81$ ). There were nine statements that recorded the mean value exceeded 4.00 and the highest mean was identified on the seventh statement (mean $=4.62, \mathrm{sp}=0.55$ ). 
The seventh statement measured feedback of the students regarding their contentment in learning foreign language of their choice. This finding indicated that the main factors affecting students' interest and motivation in foreign language course were integrative and instrumental factors, namely objectives of learning that happened (Gardner, 1985).

This findings were explained further by referring to the second highest mean ( mean $=4.59, \mathrm{sp}=0.58$ ) identified from statement "I am interested to enroll in a foreign language course of my choice that is offered at this university" and also at the third highest mean (mean $=4.52, s p=0.66$ ), on the statement "I am very happy to learn the foreign language of my choice".

Based on the highest mean value, the study found out that the interest and motivation of students in learning foreign languages were influenced by internal factors, such as the student's favorite, interest and enjoyment in learning foreign languages. In addition, students also provided feedback that foreign language course was very interesting compared to other subjects (mean $=4.29, \mathrm{sp}=$ 0.75 ) and they also showed a tendency to learn foreign languages at a higher level (mean $=4.29, \mathrm{sp}$ $=0.84)$.

At the same time, students acknowledged that they have interest in listening to foreign language songs (mean $=4.13, \mathrm{sp}=0.90$ ). There are two statements that recorded the lowest mean which were the fourth statement (mean $=3.91, \mathrm{sp}=1.20)$ and the third statement (mean $=3.98, \mathrm{sp}=0.87$ ) because learning occurred due to the interest to learn the language because of instrumental factors that were fun and enjoyment, not on the basis of integrative factors namely a will or desire to become members of the community of that particular languages. For that reason, the third and fourth statement were recorded the lowest mean.

"I enrolled in the foreign language of my choice in order to be able to understand films in the language", This finding suggested that the main perception of foreign language courses students is by learning foreign languages they could understand films of these languages. It was related closely with the student's interest in listening to the songs of foreign language that is being learned. This situation showed that the student made the medium of films and songs as alternatives in learning to master the language learned.

"I chose to learn this foreign language in order to get better job after graduation", "Skills in foreign language that I have chosen help me to understand the cultures of native speaker" and "the need of mastering foreign language of my choice is due to its importance in the global level and for the purpose of future". This matter showed that the instrumental factor play an important role in influencing learning process and the selection of languages learned (Gardner, 1985). These four statements that recorded mean values of more than 4.00 .

In addition, the study found out that the students showed perceptions that they have opportunity to get better job and are able to understand cultures of the speakers when they have knowledge of their selected foreign language. At the same time, students showed perceptions that mastering foreign language is important as it perceived as essential at the global level and also for their future. It can be seen in the mean value of the fourth statement (mean $=4.13, \mathrm{sp}=0.82$ ).

However, most of the students involved in this study (61.1\%) disagree with the last statement "I am considered as smart when knowing a foreign language, especially the language of my choice". This means that student's perception of the word 'smart' is too large because the student has yet to reach that level as they are at the beginner level of learning the chosen language. This is consistent with 
what was said by Gardner (1985) that intelligence is considered to determineto which extent individuals can understand all assignments and explanations given during the process of language learning. On the other hand, according to Cook (1991), language tendency is the student's ability to learn a second language in academic classes and it is associated with the intelligence of students.

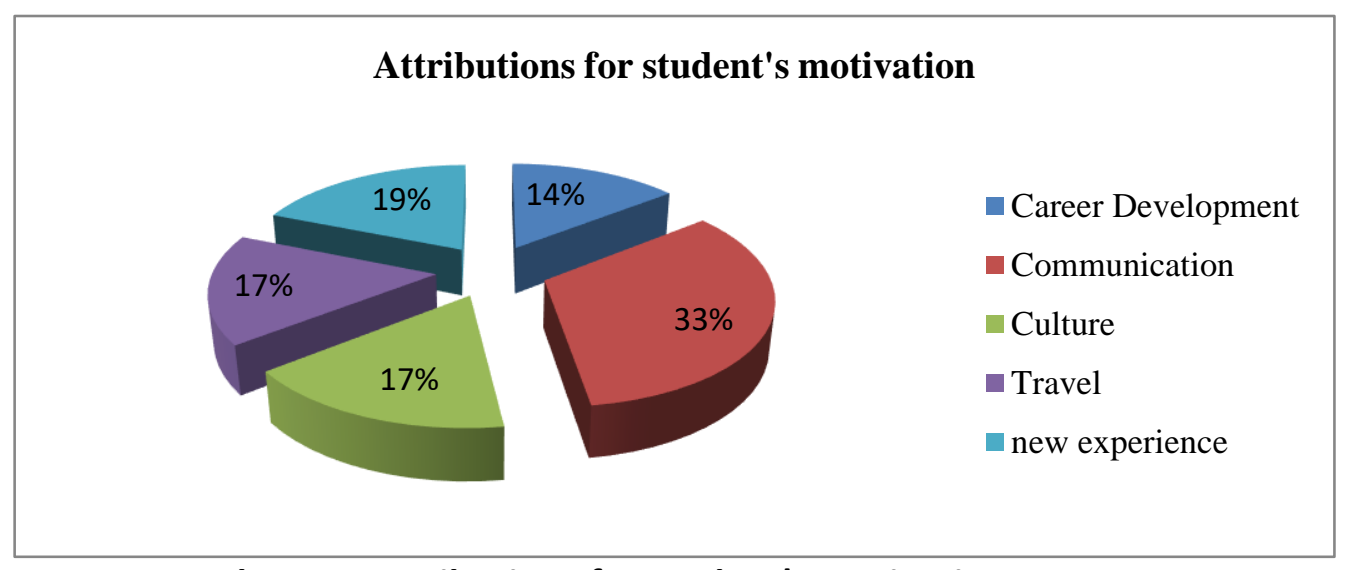

Chart 1 : Attributions for student's motivation

The survey in chart 1 is concerned with the factors that motivate the students to learn foreign languages. Some students are motivated intrinsically in that they learn foreign languages for the purpose of communicating with foreigners. 33\% the students learn the languages because they want to communicate with the native speakers. $19 \%$ of the students said that they want to learn a new thing and challenge themselves. Learning a new thing will give them a good experience and the learning process was fun and enjoyment. $17 \%$ of the students are interested in Spanish, German and Japanese culture. They wanted to understand better the culture and subsequently they anticipated to be accepted in the language community. Meanwhile, some of the students are motivated due to the extrinsic factors such as for the purpose of career development. They are concern about their future and they hope this skill can benefits them after graduation. $17 \%$ of the students are motivated to learn as they want to access to information or travel.

Data showed student's perceptions or motivation of learning foreign languages such as Japanese, German, and Spanish were at the positive level. It was associated with the orientation that was the purposes of the learning (Gardner, 1985). Findings indicated that students learned languages in this study because of integrative factor, that is to understand what has been spoken by the second community, and to help students to understand cultures of the community speaker. Student's perception is related to the instrumental factors that are for the purpose of understanding and benefits for oneself other than to get a good job and important for the future. This shows the instrumental factors is more influencing in student's learning process (Gardner, 1985).

\section{The Level of Attitudes}

Student's attitudes towards foreign language courses in this study are shown in Table 5. Clear division of categories were based on five levels which were; very negative, negative, neutral, positive and very positive. 
INTERNATIONAL JOURNAL OF ACADEMIC RESEARCH IN BUSINESS AND SOCIAL SCIENCES Vol. 9, No. 1, Jan, 2019, E-ISSN: 2222-6990 @ 2019 HRMARS

\begin{tabular}{|c|c|c|c|c|c|c|}
\hline No & Statement & Disagree & Agree & Mean & sp & Level \\
\hline \multirow[t]{3}{*}{1} & \multirow{3}{*}{$\begin{array}{l}\text { I enrolled in foreign language course } \\
\text { of my choice in order to improve my } \\
\text { grade when I graduate later. }\end{array}$} & 28 & 62 & \multirow[t]{3}{*}{3.88} & \multirow[t]{3}{*}{1.01} & \multirow[t]{3}{*}{4} \\
\hline & & & & & & \\
\hline & & $31.1 \%$ & $68.9 \%$ & & & \\
\hline \multirow[t]{2}{*}{2} & \multirow{2}{*}{$\begin{array}{l}\text { I will apply skills of foreign language } \\
\text { that I have chosen in and outside of } \\
\text { classroom. }\end{array}$} & 28 & 62 & \multirow[t]{2}{*}{3.88} & \multirow[t]{2}{*}{0.84} & \multirow[t]{2}{*}{4} \\
\hline & & $31.1 \%$ & $68.9 \%$ & & & \\
\hline \multirow[t]{2}{*}{3} & \multirow{2}{*}{$\begin{array}{l}\text { Mastering foreign language of my } \\
\text { choice enable me to be confident is } \\
\text { communicating with native speaker. }\end{array}$} & 27 & 63 & \multirow[t]{2}{*}{3.89} & \multirow[t]{2}{*}{0.84} & \multirow[t]{2}{*}{3} \\
\hline & & $30 \%$ & $70 \%$ & & & \\
\hline \multirow[t]{2}{*}{4} & I learn foreign language of my choice & 37 & 53 & \multirow[t]{2}{*}{3.66} & \multirow[t]{2}{*}{0.95} & \multirow[t]{2}{*}{4} \\
\hline & $\begin{array}{l}\text { cultural activity of native } \\
\text { community. }\end{array}$ & $41.1 \%$ & $58.9 \%$ & & & \\
\hline \multirow[t]{2}{*}{5} & If there is a program related to & 15 & 75 & \multirow[t]{2}{*}{4.21} & \multirow[t]{2}{*}{0.77} & \multirow[t]{2}{*}{4} \\
\hline & I will watch it. & $16.7 \%$ & $83.3 \%$ & & & \\
\hline \multirow[t]{2}{*}{6} & \multirow{2}{*}{$\begin{array}{l}\text { I will search for additional sources } \\
\text { about foreign language of my choice } \\
\text { such as on certain website. }\end{array}$} & 14 & 76 & \multirow[t]{2}{*}{4.17} & \multirow[t]{2}{*}{0.67} & \multirow[t]{2}{*}{4} \\
\hline & & $15.6 \%$ & $84.4 \%$ & & & \\
\hline \multicolumn{2}{|c|}{ Total } & & & 3.94 & 0.91 & 4 \\
\hline
\end{tabular}

Guide to grading levels are; Level 1:1.00-1.49 very negative, Level 2:1.50-2.49 negative, Level 3:2.50 - 3.49 neutral, Level 4:3.50 - 4.49 positive, and Level 5:4.50-5.00 very positive.

Table 5: Level of Attitude

In overall, this study found that the student's attitudes were at the positive level (mean $=3.94, \mathrm{sp}=$ 0.91). There were two statements that recorded mean value more than 4.00 which was the fifth statement ( mean $=4.21, \mathrm{sp}=0.77)$, and the sixth statement (mean $=4.17, \mathrm{sp}=0.67)$. Referring to the two highest mean values, the study found out that students were positive towards foreign language by watching foreign language programs. In addition, they also took initiative to find additional resources on website. The percentage of students who agreed with both statementswere high which were $84.4 \%$ and $83.3 \%$.

In the meantime, students who were involved in this study believed that the mastery of foreign language would help them to be more confident in communicating with native speakers ( $m e a n=$ $3.89, \mathrm{sp}=0.84$ ). Furthermore, the students also showed tendency to use the chosen foreign language skills in and outside classes (mean $=3.88, \mathrm{sp}=0.84$ ). It can be seen based on the percentage of students who agreed with the statement which was (68.9\%).

The study also found out that the students believed that the selection of foreign language courses could improve their grades (mean $=3.88, \mathrm{sp}=1.01$ ). It is shown that instrumental factor plays an important role on the student's attitudes. The lowest mean was identified for the fourth statement (mean $=3.66, \mathrm{sp}=0.95$ ), which was "I learn foreign language of my choice in order to be easy to involve in cultural activity of native community." This finding meant that the native speaker of the language was limited in Malaysia and the opportunity to engage in cultural activity of the community 
INTERNATIONAL JOURNAL OF ACADEMIC RESEARCH IN BUSINESS AND SOCIAL SCIENCES Vol. 9, No. 1, Jan, 2019, E-ISSN: 2222-6990 @ 2019 HRMARS

was very less. This showedthat integrative orientation was not a major factor that influenced student's language learning. According to Gardner (1985) in the theory of Socio-Educational, integrative orientation occurred when students learned a second language for the purpose of communicating with native speakers and being accepted as member of the community of that particular language.

\section{The Relation of Motivation with Attitudes}

Table 6 shows Pearson correlation analysis $(r)$ to determine the relationship between two independent variables namely motivation with dependent variables namely attitudes.

\begin{tabular}{lll}
\hline $\begin{array}{l}\text { Independent } \\
\text { Variables }\end{array}$ & $\begin{array}{l}\text { Dependent Variables: } \\
\text { Attitude }\end{array}$ & $\begin{array}{l}\text { Strength of the } \\
\text { Relationship }\end{array}$ \\
\hline Motivation & $0.78^{* *}$ & Strong
\end{tabular}

Table 6: Pearson correlation test for the relationship of motivation with attitude

Based on the significant $p$ value that was less than 0.05 , the variable had significant relationship with attitudes. Referring to the Coefficient of Relationship Strength (Cohen, 1988) in Table 7, relationship strength of motivation with attitudes $(r=0.78, p<0.05)$ were strong. It showed that the more motivated learners towards foreign language courses, the more positive their attitudes towards the language course would be. This indicated that students with high integrative and instrumental oriented in language learning could possess strong interests, perception and attitudes in learning and would show positive attitude towards learning.

\begin{tabular}{ll}
\hline Size & Explanation \\
\hline$r=.10$ until .29 ataur $=-.10$ until -.29 & Small \\
$r=.30$ until .49 ataur $=-.30$ until -.49 & Medium \\
$r=.50$ until 1.0 ataur $=-.50$ until -1.0 & Strong \\
\hline
\end{tabular}

\section{Conclusion}

Table 7: Coefficient interpretation of relationship strength

In order to achieve successful language learning, the students must pay attention to the affective factors that can help them to develop the learning abilities. Motivation and attitude are the most important and often discussed emotional factors. They plan a vital part in foreign language learning. The motivated students spend effort, are persistent and attentive to the task at hand, have goals, desires and aspirations from success concerning success and/or failure, are aroused and make use of strategies to aid in achieving goals. Student's learning interest can be motivated by enhancing their positive emotional experiences. In overall, students showed high motivation and good attitude in learning Japanese, Spanish and German language in UPSI. Positive attitudes were able to help students during the teaching and learning process. This study could be as guidance to all parties who are related to the learning of foreign languages in Malaysia mainly to lecturers, language teachers in order to help students to master the language effectively. Positive attitude of the students should be maintained and continued throughout the learning process to ensure the learning objectives are achieved. Indirectly, this study also describes on the attitudes, interests and perceptions of students 
INTERNATIONAL JOURNAL OF ACADEMIC RESEARCH IN BUSINESS AND SOCIAL SCIENCES

Vol. 9, No. 1, Jan, 2019, E-ISSN: 2222-6990 @ 2019 HRMARS

towards learning foreign languages in UPSI in particular, Spanish language, German language and Japanese Language.

\section{Acknowledgment}

This paper is based on the research project entitled Pengaruh Sikap Dalam Pembelajaran Bahasa Asing dalam Kalangan Pelajar Di Universiti Pendidikan Sultan Idris. The authors would like to extend their gratitude to the Research Management and Innovation Centre (RMIC), Sultan Idris Education University, Perak, Malaysia for the University Research Grant (Code 2015-0046-106-01) that helped fund the research.

\section{References}

Amzah, N., Hieda. N., \& Shabudin. M. (2012). Sikap Mahasiswa UKM Terhadap Bahasa Jepun : Satu kajian kes, Jurnal of Language Studies, 14 (1), Universiti Kebangsaan Malaysia. Retrieved from http://ejournal.ukm.my/gema/article/view/5595/3216

Baker, C. (1992). Atittudes and language. Avon, England: Multilingual Matters Ltd.

Chua, Y. P. (2008). Asas statistik penyelidikan: Analisis data skala ordinal dan skala nominal. McGraw-Hill Malaysia Sdn. Bhd: Kuala Lumpur

Cohen, J. (1988) Statistical power analysis for the behavioral sciences (2nd ed.) Hillsdale, NJ: Erlbaum.

Firdaus, M. (2003). Sikap dan motivasi pembelajaran bahasa Inggeris serta implikasinya terhadap pencapaian. Fakulti Pendidikan, Universiti Kebangsaan Malaysia, Bangi.

Frey, K. (2014). The case for motivated reasoning. Psychological Bulletin,108(3), 480.

Fuller, E. G. (1987). How to learn a foreign language. Washington:Storm King Press.

Gardner, R. C. (1985). Social psychology and second language learning: The role of attitudes \& Motivation. Bungay Suffolk : Edward Arnold.

Gardner, R. C. \& Lambert, W.E. (1972). Attitudes \& motivation in second language learning. Rowley, M.A : Newbury House Publisher.

Hair, J. F., Black, W.C., Babin, B. J., \& Anderson, R. E. (2010) Multivariate data analysis (7th Edition), Pearson Education: Upper Saddle River.

Hieda, N., \& Shabudin, M. (2014) Sikap Mahasiswa UKM Terhadap Bahasa Jepun : Satu Kajian Kes. GEMA Online ${ }^{\circledR}$ Journal of Language Studies. 14 (1) : 135- 150. Retrieved from http://ejournal.ukm.my/gema/article/view/5595

Ishida, S. (1998). Motivation to learn and image of the Japanese language in Australian students. Bulletin of the Faculty of Education,35, 57-66.

Krejcie, R. V., \& Morgan, D. W. (1970). Determining sample size for research activities educational \& Pschological Measurement, 30, 607-610.

Littlewood, W. (1984). Foreign and second language learning. Language acquisition research and its complications for the classroom. Cambrigde : Cambridge University Press

Mao, H., \& Fukuda, M. (2010) A comparison on learning motivation between major Japanese learners in China and major Chinese learners in Japan. Language and culture, 23, 209-232.

University of Brasov Series VII: Social Sciences • Law • Vol. 4 (53) No. 2 -2011. 
INTERNATIONAL JOURNAL OF ACADEMIC RESEARCH IN BUSINESS AND SOCIAL SCIENCES

Vol. 9, No. 1, Jan, 2019, E-ISSN: 2222-6990 @ 2019 HRMARS

Mat, C. A., \& Goh, Y.S. (2010). Situasi pembelajaran bahasa asing di Institusi Pengajian Tinggi: Perbandingan antara Bahasa Arab, Bahasa Mandarin dan Bahasa Perancis. Asean Journal of Teaching and Learning in Higher Education, 12 (2), 9-20. Retrieved from http://ejournal.ukm.my/ajtlhe/article/view/10494/3479

Redzuan, M. A. (2005). Sikap pelajar Cina terhadap pembelajaran bahasa Jepun di Universiti Putra Malaysia. Tesis Sarjana Pengajian Bahasa Moden. Universiti Malaya: Kuala Lumpur

Sakuragi, T. (2006). The relationship between attitudes towards language study and cross-cultural attitudes. International Journal of Intercultural Relations, 30, 19-31. doi:10.1016/j.ijintrel.2005.05.017

Seraai, M. A. (2009). Orientasi dan motivasi pelajar dalam pembelajaran Bahasa Sepanyol, MA Thesis. Universiti Malaya: Kuala Lumpur. Retrieved form http://studentsrepo.um.edu.my/id/eprint/3280

Yusri, G., Nik Yusoff, N. M. R., \& Shah, M. P. (2010). Sikap pelajar terhadap pembelajaran kemahiran lisan bahasa Arab di Universiti Teknologi Mara (UiTM) GEMA Online ${ }^{\circledR}$ Journal of Language Studies. (3) : 15- 33. Retrieved from http://journalarticle.ukm.my/2334

Zhoa, L. (2015). The influence of Learner's Motivation and Attitudes on second Language, Theory and Practice In Language Studies, 5( 11). doi : http://dx.doi.org/10.17507/tpls.0511.18

Zubairi, A. M., \& Sarudin. I. (2009). Motivation to learn a foreign language in Malaysia. GEMA Online ${ }^{\circledR}$ Journal of Language Studies. 9(2), 73-87. Retrieved from http://ejournal.ukm.my/gema/article/view/158 